Jurnal SOSIO DIALEKTIKA 6 (1) (2021)

P-ISSN: 2540.8941 e-ISSN: 2623.2944

sosiodialektika@unwahas.ac.id
Determinan Variabel Demografi

Terhadap Cerai Hidup Wanita

Di Pulau Sumatera: Survei

Demografi Dan Kesehatan

Indonesia 2017

\title{
DETERMINAN VARIABEL DEMOGRAFI TERHADAP CERAI HIDUP WANITA DI PULAU SUMATERA: SURVEI DEMOGRAFI DAN KESEHATAN INDONESIA 2017
}

\author{
Angga Setyawan \\ Prodi Kependudukan Program Pasca Sarjana Universitas Sriwijaya \\ Email: anggasetyawan4994@gmail.com
}

\begin{abstract}
The purpose of this study was to analyze the demographic variables that affect the probability (chance) of divorce for women on the island of Sumatra. This research is a quantitative analysis, using secondary data from the 2017 Indonesian Demographic and Health Survey (IDHS) with logistic regression analysis method. The results showed that three variables that significantly influence the high and low chance of divorce for women are wife's education, number of children and wife's occupation. The wife's education has a significant effect on the chance of a woman's divorce, with the wife's education coefficient is positive, which means that the lower the wife's education, the higher the chance for a wife to be divorced. The coefficient value of the number of children is positive, which means that the fewer children $(</=2$ children), the higher the chances of women experiencing divorce. The wife's occupation variable shows a negative coefficient, which means that a wife who works as an informal worker has a lower chance of experiencing divorce than a wife who works as a formal worker. Meanwhile, the age at first marriage variable does not significantly affect the chances of a woman's divorce.
\end{abstract}

Keywords: Divorce, Woman's Divorce, Demographic Variable, IDHS 2017

\section{A. PENDAHULUAN}

Perkawinan merupakan ikatan pertama yang membentuk sebuah hubungan rumahtangga. Perkawinan merupakan suatu peristiwa yang sakral dan sangat penting dalam kehidupan keluarga (Prasetyo, 2017). Dalam sebuah perkawinan sangat dibutuhkan persiapan baik mental maupun materiel. Seseorang yang telah mengambil keputusan untuk menikah artinya telah siap dengan segala resiko yang dihadapi dalam hubungan perkawinan. Menurut Lembaga Demografi Universitas Indonesia, (2016), perkawinan merupakan penyatuan legal antara dua orang yang berlainan jenis kelamin sehingga menimbulkan hak dan kewajiban akibat perkawinan. Sedangkan 
Jurnal SOSIO DIALEKTIKA 6 (1) (2021)

P-ISSN: 2540.8941 e-ISSN: 2623.2944

sosiodialektika@unwahas.ac.id
Determinan Variabel Demografi

Terhadap Cerai Hidup Wanita

Di Pulau Sumatera: Survei

Demografi Dan Kesehatan

Indonesia 2017

menurut Dunvall dan Miller, (1998), perkawinan dikatakan sebagai hubungan antara pria dan wanita yang telah diakui dalam masyarakat serta memiliki hak dan kewajiban sebagai suami dan istri. Tujuan dari perkawinan adalah membentuk keluarga (rumah tangga) yang bahagia lahir maupun batin dan kekal berdasarkan Ketuhanan Yang Maha Esa (UU No. 1 tahun 1974). Dalam mencapai keluarga yang bahagia banyak keluarga yang gagal mengupayakan keharmonisannya, akan timbul sebuah benturan yang tidak pernah mereka harapkan yaitu perceraian (Matondang, 2014).

Badan Pusat Statistik menjelaskan bahwa status perkawinan sebagai ukuran kesejahteraan biasanya dilihat dari jumlah penduduk yang kawin pada usia muda dan tingginya angka perceraian. Perceraian merupakan titik puncak dari pengumpulan berbagai permasalahan yang menumpuk beberapa waktu sebelumnya dan jalan terakhir yang harus ditempuh ketika hubungan perkawinan itu sudah tidak dapat dipertahankan lagi (Dariyo, 2003). Perceraian dianggap sebagai satu-satunya jalan terbaik dan sudah tidak ada jalan keluar lagi bagi pasangan suami istri untuk mengakhiri hubungan dengan pasangannya (Widayanti, 2014). Kasus perceraian kerap sekali terjadi baik dikalangan pejabat negara, public figure dan masyarakat umum. Pergeseran budaya dimasyarakat saat ini telah mengubah fenomena perceraian menjadi hal yang umum untuk dilakukan (Yunus, dkk 2012). Berdasarkan data Badan Pusat Statistik (BPS) Indonesia, angka cerai hidup di Indonesia selalu mengalami peningkatan sebesar 0,1 persen pertahun antara tahun 2012-2016 dan yang menjadi menarik disini, angka cerai hidup wanita dengan pria sangat jauh berbeda. Persentase cerai hidup wanita di pada tahun 2016 sebesar 2,6 persen. Sedangkan cerai hidup laki-laki sebesar 1,3 persen. Tahun 2017, angka cerai hidup wanita indonesia terus naik hingga mencapai 2,8 persen (SDKI 2017).

Perceraian tidak akan terjadi tanpa adanya alasan kuat yang menjadi penyebab suami dan istri tidak dapat hidup bersama lagi. Hal tersebut terjadi apabila usaha untuk menyatukan kembali suami dan istri tidak dapat tercapai (Pasal 39 ayat 2 UU No. 1 tahun 1974). Matondang, (2014), 
Jurnal SOSIO DIALEKTIKA 6 (1) (2021)

P-ISSN: 2540.8941 e-ISSN: 2623.2944

sosiodialektika@unwahas.ac.id
Determinan Variabel Demografi

Terhadap Cerai Hidup Wanita

Di Pulau Sumatera: Survei

Demografi Dan Kesehatan

Indonesia 2017

membagi faktor-faktor yang memiliki pengaruh signifikan terhadap perceraian dalam beberapa faktor yaitu: menikah usia muda, ekonomi, belum memiliki keturunan dan suami sering melakukan kekerasan. Sedangkan Oktary, (2014), menyebutkan faktor yang mempengaruhi perceraian secara signifikan terjadinya perceraian dengan menempatkan faktor tingkat pendidikan, jenis pekerjaan, pendapatan, jumlah anak. Namun untuk umur kawin pertama tidak mempengaruhi perceraian secara signifikan.

Di Pulau Sumatera, berdasarkan data BPS angka cerai hidup wanita selalu mengalami peningkatan, hal tersebut dapat dilihat pada tahun 2012 sebesar 2,0 persen, 2013 sebesar 2,3 persen, 2014 sebesar 2,6 persen, 2015 sebesar 2,7 persen, 2016 sebesar 2,7 persen, dan tahun 2017, angka cerai hidup wanita mencapai 2,8 persen (Badan Pusat Statistik indonesia).

Dari beberapa hal tersebut, maka tujuan dari penelitian ini adalah menganalisis faktor-faktor yang secara signifikan berpengaruh terhadap probabilitas cerai hidup wanita di Pulau Sumatera dengan menggunakan data Survei Demografi dan Kesehatan Indonesia tahun 2017 khususnya yang berkaitan dengan cerai hidup wanita.

\section{B. METODE PENELITIAN}

Penelitian ini merupakan analisis kuantitatif dengan menggunakan data sekunder dari SDKI 2017. Pelaksaan SDKI di lakukan di 34 Propinsi yang ada di Indonesia pada Mei sampai juli 2017. SDKI 2017 bertujuan untuk menyediakan estimasi terbaru indikator dasar demografi dan kesehatan serta menyediakan gambaran menyeluruh tentang kependudukan dan kesehatan. Dalam penelitian ini, sampel penelitian ditentukan sesuai tujuan penelitian dengan karakteristik status perkawinan. Sampel WUS berjumlah 344 yang berstatus cerai hidup di 10 Provinsi yang ada di Pulau Sumatera (Aceh, Sumatera Utara, Sumatera Barat, Riau, Jambi, Sumatera Selatan, Bengkulu, Lampung, Bangka Belitung, Kepulauan Riau). 
Jurnal SOSIO DIALEKTIKA 6 (1) (2021)

P-ISSN: 2540.8941 e-ISSN: 2623.2944

sosiodialektika@unwahas.ac.id
Determinan Variabel Demografi

Terhadap Cerai Hidup Wanita

Di Pulau Sumatera: Survei

Demografi Dan Kesehatan

Indonesia 2017

Variabel bebas yang digunakan pada penelitian ini merupakan faktor yang mempengaruhi cerai hidup wanita berdasarkan teori dan kajian terdahulu yang terkait. Kemudian di sesuaikan dengan data mentah (Raw data) pada SDKI 2017 seperti: pendidikan istri, umur kawin pertama, jumlah anak, dan pekerjaan istri yang dipergunakan untuk melihat bagaimana faktor tersebut mempengaruhi probabilitas cerai hidup wanita. Model regresi logistik dipergunakan untuk menjawab hipotesis dari penelitian ini seperti: a) semakin rendah pendidikan istri, maka semakin tinggi peluang istri untuk mengalami cerai hidup wanita, b) semakin rendahnya usia kawin pertama, maka semakin tinggi peluang wanita mengalami cerai hidup wanita, c) semakin sedikitnya jumlah anak yang dimiliki, maka semakin tinggi peluang istri untuk mengalami cerai hidup wanita, dan d) istri bekerja sebagai pekerja formal, maka peluanguntuk mengalami cerai hidup wanita lebih tinggi. Model Regresi logistik juga dipergunakan untuk mengkaji faktor-faktor yang mempengaruhi variabel dependen terhadap variabel independen. Metode analisis yang digunakan pada penelitian ini adalah analisis regresi logistik dan diolah menggunakan komputer dengan program Statistical Program and Service Solution (SPSS). Model persamaan pada penelitian yaitu:

$$
\operatorname{Ln} \frac{Y}{1-Y}=\beta_{0}+\beta_{1} X_{1}+\beta_{2} X_{2}+\beta_{3} X_{3}+\beta_{4} X_{4}
$$

Dimana:

$\mathrm{Y} \quad=$ Peluang seorang istri pada status perkawinan

$$
\text { ( } 1=\text { cerai hidup; } 0=\text { tidak cerai hidup) }
$$

$\beta_{0}=$ Konstanta

$\beta_{1-4}=$ Parameter dugaan (koefisien logistic)

$\mathrm{X}=$ Variabel bebas disajikan pada tabel 1 
Jurnal SOSIO DIALEKTIKA 6 (1) (2021)

P-ISSN: 2540.8941 e-ISSN: 2623.2944

sosiodialektika@unwahas.ac.id
Determinan Variabel Demografi

Terhadap Cerai Hidup Wanita

Di Pulau Sumatera: Survei

Demografi Dan Kesehatan

Indonesia 2017

\begin{tabular}{|c|c|c|c|c|}
\hline Variabel & & & $\begin{array}{l}\text { Frekuensi } \\
\text { (n) }\end{array}$ & $\begin{array}{c}\text { Persentase } \\
(\%)\end{array}$ \\
\hline Variabel Terikat & $\begin{array}{l}\text { Status Perkawinan } \\
\text { (Y) }\end{array}$ & $\begin{array}{l}\text { Tidak Cerai Hidup } \\
\text { Cerai Hidup }\end{array}$ & $\begin{array}{c}8768 \\
344\end{array}$ & $\begin{array}{c}96,2 \\
3,8\end{array}$ \\
\hline \multirow[t]{8}{*}{ Variabel Bebas } & Pendidikan istri $\left(\mathrm{X}_{1}\right)$ & $<$ SMA & 299 & 3,9 \\
\hline & & $>/=\mathrm{SMA}$ & 45 & 3,1 \\
\hline & Umur Kawin & $<20$ & 178 & 3,9 \\
\hline & Pertama $\left(\mathrm{X}_{2}\right)$ & $>20$ & 166 & 3,7 \\
\hline & Jumlah anak $\left(\mathrm{X}_{3}\right)$ & $</=2$ & 304 & 5,9 \\
\hline & & $<2$ & 40 & 3,6 \\
\hline & Pekerjaan Istri $\left(\mathrm{X}_{4}\right)$ & Pekerja Informal & 146 & 2,5 \\
\hline & & Pekerja Formal & 198 & 6,0 \\
\hline
\end{tabular}

Sumber: SDKI (2017)

\section{HASIL DAN PEMBAHASAN}

Dalam hasil penelitian ditampilkan analisis regresi logistik variabel independen terhadap variabel dependen. Data yang digunakan berupa Data Survei Demografi dan Kesehatan Indonesia (SDKI) tahun 2017 yaitu:

Tabel 2. Hasil Analisis Regresi Logistik

\begin{tabular}{|c|c|c|c|c|c|c|c|c|}
\hline & \multirow{2}{*}{ Koefisien } & \multirow{2}{*}{ S.E. } & \multirow{2}{*}{ Wald } & \multirow{2}{*}{ Df } & \multirow{2}{*}{ Sig. } & \multirow{2}{*}{$\operatorname{Exp}(B)$} & \multicolumn{2}{|c|}{$95 \%$ C.I.for EXP (B) } \\
\hline & & & & & & & Lower & Upper \\
\hline $\begin{array}{l}\text { Pendidikan } \\
\text { Istri }\end{array}$ & .531 & .174 & 9.323 & 1 & .002 & 1.700 & 1.209 & 2.391 \\
\hline $\begin{array}{l}\text { Umur Kawin } \\
\text { Pertama }\end{array}$ & .111 & .118 & .885 & 1 & .347 & 1.117 & .887 & 1.407 \\
\hline Jumlah Anak & .538 & .178 & 9.161 & 1 & .002 & 1.712 & 1.209 & 2.426 \\
\hline $\begin{array}{l}\text { Pekerjaaan } \\
\text { Istri }\end{array}$ & -.984 & .114 & 75.099 & 1 & .000 & .374 & .299 & .467 \\
\hline Constant & -3.269 & .160 & 418.624 & 1 & .000 & .038 & & \\
\hline
\end{tabular}

Sumber: Data SDKI diolah, 2017

Pendidikan istri dikelompokkan menjadi 2 kategori yaitu: Pendidikan rendah (</=SMA), dan pendidikan tinggi ( $>$ SMA). Hasil analisis diperoleh bahwa wanita yang berstatus cerai hidup dengan jenjang 
Jurnal SOSIO DIALEKTIKA 6 (1) (2021)

P-ISSN: 2540.8941 e-ISSN: 2623.2944

sosiodialektika@unwahas.ac.id
Determinan Variabel Demografi

Terhadap Cerai Hidup Wanita

Di Pulau Sumatera: Survei

Demografi Dan Kesehatan

Indonesia 2017

pendidikan rendah memiliki persentase sebesar 3,9 persen. Sedangkan istri dengan pendidikan tinggi memiliki persentase sebesar 3,1 persen

Hasil penelitian menunjukkan bahwa variabel pendidikan istri berpengaruh secara signifikan terhadap peluang tinggi rendahnya cerai hidup wanita. Artinya, istri yang berpendidikan rendah memiliki peluang lebih tinggi terhadap cerai hidup wanita, dibandingkan dengan istri yang memiliki pendidikan tinggi. Menurut Notoatmodjo, (2010), Pendidikan merupakan upaya untuk meningkatkan kualitas sumber daya manusia menuju kualitas yang mempengaruhi orang lain, baik individu, kelompok masyarakat, sehingga mereka dapat melakukan apa yang diharapkan oleh pelaku pendidikan. Pendidikan istri, baik wanita yang berstatus cerai hidup atau tidak cerai hidup dikelompokkan menjadi 2 kategori yaitu: Pendidikan rendah ( $</=$ SMA), dan pendidikan tinggi ( $>$ SMA). Hasil analisis diperoleh bahwa wanita yang berstatus cerai hidup dengan jenjang pendidikan rendah memiliki persentase sebesar 3,9 persen. Sedangkan istri dengan pendidikan tinggi memiliki persentase sebesar 3,1 persen

Pendidikan istri dengan p-value (signifikansi) sebesar 0,002 berarti pvalue $<\alpha(0,05)$ sehingga dikatakan bahwa $\mathrm{H}_{1}$ terima dan $\mathrm{H}_{0}$ ditolak, artinya terdapat pengaruh yang signifikan antara pendidikan istri dengan peluang tinggi atau rendahnya cerai hidup wanita, atau dengan kata lain semakin rendah pendidikan istri akan semakin tinggi peluang terhadap cerai hidup wanita.

Nilai odds ratio pendidikan istri adalah sebesar 1,700 artinya kecenderungan istri dengan tingkat pendidikan yang lebih rendah untuk cerai hidup sebesar 1,700 kali lebih besar daripada istri dengan pendidikan yang lebih tinggi pada cerai hidup wanita.

Hasil temuan dalam penelitian ini sejalan dengan hasil temuan yang dilakukan oleh Yunus, (2012), wanita dengan tingkat pendidikan yang rendah mengalami cerai hidup secara signifikan dengan persentase sebesar 94.85 persen. Hal serupa juga didukung berdasarkan hasil penelitian dari Khumas, A, (2015), faktor tidak langsung yang turut berkontribusi terhadap 
Jurnal SOSIO DIALEKTIKA 6 (1) (2021)

P-ISSN: 2540.8941 e-ISSN: 2623.2944

sosiodialektika@unwahas.ac.id
Determinan Variabel Demografi

Terhadap Cerai Hidup Wanita

Di Pulau Sumatera: Survei

Demografi Dan Kesehatan

Indonesia 2017

intensi cerai hidup wanita berdasarkan model explanatory adalah faktor pendidikan, yaitu semakin rendahnya pendidikan istri, maka intensi cerai semakin tinggi.

Wanita berpendidikan tinggi sangat mungkin sekali untuk memiliki pekerjaan sebagai pekerja formal yang mengikat dirinya untuk tidak bercerai dan dalam proses pengurusan izin bercerai yang panjang dan tidak mudah. Sehingga mau tidak mau mereka mempertahankan pernikahannya. Menurut Mahapadiat, (2019), setiap Aparatur Sipil Negara (pekerja formal)

yang akan melakukan perceraian harus melalui proses izin di Instansi terkait, dan bagi yang berkedudukan sebagai penggugat berkewajiban mengajukan permohonan tertulis berupa permohonan izin untuk melakukan perceraian serta alasan izin untuk bercerai dapat diberikan oleh pejabat apabila tidak bertentangan dengan ajaran atau peraturan agama yang dianut nya.

Dari hasil diatas dapat ditarik kesimpulan bahwa mengapa wanita dengan pendidikan tinggi memiliki peluang lebih cerai hidup lebih rendah, karena wanita berpendidikan tinggi kemungkinan besar bekerja di sektor formal, sehingga dalam proses pengurusan izin sangat sulit yang menyebabkan mereka enggan untuk mengurusnya.

Jumlah anak dibagi menjadi 2 kategori yaitu memiliki anak sedikit $(</=2)$ dan memiliki banyak anak $(>2)$. Wanita yang berstatus cerai hidup yang memiliki anak sedikit $(</=2)$ sebanyak 304 responden atau sebesar 5,9 persen. Sedangkan responden yang berstatus cerai hidup dengan memiliki anak banyak yaitu sebanyak 40 responden dengan persentase sebesar 3,6 persen.

Variabel jumlah anak menunjukkan pengaruh yang signifikan terhadap cerai hidup wanita. Artinya banyak atau sedikitnya anak yang dimiliki berpeluang terhadap tinggi rendahnya cerai hidup wanita. Hasil penelitian menunjukkan bahwa wanita yang memiliki jumlah anak sedikit berpeluang lebih tinggi terhadap cerai hidup wanita dibandingkan dengan wanita yang memiliki jumlah anak banyak. 
Jurnal SOSIO DIALEKTIKA 6 (1) (2021)

P-ISSN: 2540.8941 e-ISSN: 2623.2944

sosiodialektika@unwahas.ac.id
Determinan Variabel Demografi

Terhadap Cerai Hidup Wanita

Di Pulau Sumatera: Survei

Demografi Dan Kesehatan

Indonesia 2017

Jumlah anak dengan p-value (signifikansi) sebesar 0,002 berarti pvalue $<\alpha(0,05)$ sehingga dikatakan bahwa $\mathrm{H}_{1}$ terima dan $\mathrm{H}_{0}$ ditolak, artinya terdapat pengaruh yang signifikan antara jumlah anak dengan peluang tinggi atau rendahnya cerai hidup wanita, atau dengan kata lain semakin sedikit jumlah anak yang dimiliki akan semakin tinggi peluang cerai hidup wanita..

Nilai Odds Ratio jumlah anak adalah sebesar 1,712 artinya wanita yang mempunyai jumlah anak sedikit memiliki peluang 1,712 kali lebih besar daripada wanita yang mempunyai banyak anak.

Jumlah anak dibagi menjadi 2 kategori yaitu $</=2$ anak dan $>2$ anak. Hasil analisis diperoleh wanita yang berstatus cerai hidup memiliki $</=2$ anak sebanyak 304 responden atau sebesar 5,9 persen. Sedangkan responden yang berstatus cerai hidup dengan memiliki anak >2 yaitu sebanyak 40 responden dengan persentase sebesar 3,6 persen.

Hasil temuan dalam penelitian sejalan dengan temuan Hurlock (1993: 299), perceraian banyak terjadi karena pasangan tidak mempunyai anak atau hanya mempunyai beberapa anak ( $<2$ anak). Hasil penelitian juga didukung oleh penelitian dari Yunus, (2012), wanita yang memiliki sedikit anak menyumbang 86,26 persen kasus cerai hidup wanita.

Pembatasan kepemilikan anak pada pekerjaan sektor formal, menyebabkan seorang istri harus terikat dengan aturan pekerjaan. Menurut Mahapadiat, (2019), jumlah anak ini juga dipengaruhi dari pendidikan dan status ekonomi karena terdapat cukup banyak temuan yang memperlihatkan bahwa mereka yang berpendidikan rendah cenderung memiliki banyak anak karena persepsi dapat meringankan beban ekonomi keluarga atau membantu orang tua secara ekonomi dan yang berpendidikan tinggi cenderung mempunyai anak sedikit karena lebih mementingkan kualitas anak.

Dari hasil penelitian dapat diambil kesimpulan bahwa pembatasan dari pekerjaan menyebabkan seorang wanita yang bekerja formal terikat untuk memiliki anak sedikit, sedangkan keinginan suami untuk memiliki banyak anak menimbulkan konflik dan perdebatan antara suami dan istri yang kemudian berdampak terhadap perselingkuhan suami. 
Jurnal SOSIO DIALEKTIKA 6 (1) (2021)

P-ISSN: 2540.8941 e-ISSN: 2623.2944

sosiodialektika@unwahas.ac.id
Determinan Variabel Demografi

Terhadap Cerai Hidup Wanita

Di Pulau Sumatera: Survei

Demografi Dan Kesehatan

Indonesia 2017

Pekerjaan istri dikelompokkan menjadi 2 kategori yaitu pekerja formal (professional, manager dan administrasi, layanan) dan informal (tidak bekerja, pekerja pertanian, ibu rumah tangga). Hasil analisis diperoleh wanita yang berstatus cerai hidup dengan jenis pekerjaan sebagai pekerja formal sebanyak 198 responden dengan persentase sebesar 6,0 persen. Sedangkan responden yang berstatus cerai hidup yang memiliki pekerjaan sebagai pekerja informal sebanyak 2,5 persen.

Hasil penelitian didapatkan bahwa istri yang bekerja sebagai pekerja informal memiliki peluang lebih rendah terhadap cerai hidup wanita dibandingkan dengan istri yang bekerja sebagai pekerja formal. Pekerjaan istri dengan p-value (signifikansi) sebesar 0,002 berarti p-value $<\alpha(0,05)$ sehingga dikatakan bahwa $\mathrm{H}_{1}$ terima dan $\mathrm{H}_{0}$ ditolak, artinya terdapat pengaruh yang signifikan antara pekerjaan istri dengan peluang tinggi atau rendahnya cerai hidup wanita, atau dengan kata lain istri dengan pekerjaan sebagai pekerja informal, memiliki peluang lebih rendah untuk cerai hidup daripada istri dengan pekerjaan sebagai pekerja formal (C.I 95\%; 0,2990,467).

Nilai odds ratio pekerjaan istri adalah sebesar 0,374 artinya kecenderungan istri dengan jenis pekerjaan sebagai pekerja informal memiliki peluang 0,374 kali daripada istri dengan jenis pekerjaan sebagai pekerja formal pada cerai hidup wanita. Artinya istri yang memiliki pekerjaan formal jauh lebih tinggi peluangnya untuk mengalami cerai hidup. Hal ini dikarenakan istri yang bekerja formal tidak dapat menjalankan perannya dalam rumah tangga jika harus berperan ganda.

Hasil penelitian ini sejalan dengan penelitian yang telah dilakukan oleh Ascandra, (2019), wanita yang bekerja di sektor non pertanian dan status pekerjaan sebagai karyawan atau pegawai memberikan peluang lebih tinggi terhadap wanita untuk bercerai.

Berdasarkan penelitian dari Devi dan Firdaus, (2019), hal yang menyebabkan terjadinya perselisihan dan pertengkaran antara suami istri dalam putusan cerai talak terhadap wanita karier dikarenakan seorang istri 
Jurnal SOSIO DIALEKTIKA 6 (1) (2021)

P-ISSN: 2540.8941 e-ISSN: 2623.2944

sosiodialektika@unwahas.ac.id
Determinan Variabel Demografi

Terhadap Cerai Hidup Wanita

Di Pulau Sumatera: Survei

Demografi Dan Kesehatan

Indonesia 2017

yang memiliki pekerjaan di luar rumah di mana awalnya mereka mendapatkan izin dari suami untuk berkerja di luar rumah, akan tetapi istri tersebut tidak dapat mengatur waktu dengan baik dan tidak dapat menjalankan kewajibannya sebagaimana yang telah ia ketahui. Dari hasil penelitian Devi dan Firdaus, (2019), dapat diketahui bahwa istri dengan pekerjaan formal lebih cenderung diceraikan (talak), karena mengingat pengurusan izin bercerai pekerja formal cenderung lebih sulit dibandingkan dengan pekerja informal.

Seorang istri harus mengurus suami, anak dan rumah, dalam waktu bersamaan istri juga harus berkewajiban melakukan pengabdian terhadap pekerjaannya sesuai dengan kadar intelektual dan profesional, sehingga terkadang hal tersebut tidak dapat dilakukan secara bersamaan. Istri dengan pekerjaan sebagai pekerja formal menghabiskan waktunya untuk bekerja diluar rumah, sehingga kurangnya komunikasi antara suami istri dan ketidak mampuan istri dalam menjalankan peran ganda serta terkadang seringkali masalah kerja terbawa kedalam rumah tangga yang kemudian malah menimbulkan konflik baru dalam keluarga (Wulandari, 2013).

Dalam sebuah hubungan rumah tangga, yang bertugas sebagai pencari nafkah adalah seorang suami, dimana tugas istri hanya untuk membantu. Namun dalam sebuah rumah tangga, tingginya kebutuhan rumah tangga menyebabkan seorang istri harus merangkap tugas selain mengurus rumah tangga di rumah. Ketidakmampuan seorang suami dalam mencukupi kebutuhan ekonomi rumah tangga menyebabkan istri harus bekerja diluar rumah.

Dari hasil penelitian dapat disimpulkan bahwa, istri yang bekerja sebagai pekerja formal sering kali tidak dapat menjalankan perannya sebagai dirumah, karena kesibukan dalam pekerjaan dan ketidak mampuan seorang suami dalam mencukupi kebutuhan keluarga menyebabkan seorang istri harus bekerja diluar rumah. Hal tersebut menimbulkan ketimpangan dalam sebuah keluarga, yang berdampak terhadap ketidak harmonisan hubungan rumah tangga. 
Jurnal SOSIO DIALEKTIKA 6 (1) (2021)

P-ISSN: 2540.8941 e-ISSN: 2623.2944

sosiodialektika@unwahas.ac.id
Determinan Variabel Demografi

Terhadap Cerai Hidup Wanita

Di Pulau Sumatera: Survei

Demografi Dan Kesehatan

Indonesia 2017

Umur kawin pertama dikelompokkan menjadi 2 kategori yaitu: $<20$ tahun dan $>20$. Umur kawin pertama $<20$ tahun pada wanita yang berstatus cerai hidup memiliki jumlah sebanyak 178 responden atau persentase sebesar 3,9 persen. Sedangkan umur kawin pertama $>20$ tahun pada wanita yang berstatus cerai hidup sebanyak 166 responden atau dengan persentase sebesar 3,7 persen.

Umur kawin pertama dengan p-value (signifikansi) sebesar 0,347 berarti p-value $>\alpha(0,05)$ sehingga dikatakan bahwa $\mathrm{H}_{1}$ ditolak dan $\mathrm{H}_{0}$ diterima, artinya tidak terdapat pengaruh yang signifikan antara umur kawin pertama dengan peluang tinggi atau rendahnya cerai hidup wanita. Umur kawin pertama adalah awal mula melakukan perkawinan. Ketika seorang wanita telah menikah maka pola pikirnya telah berkembang dengan sendirinya, sehingga dalam menghadapi masalah, seiring berjalannya waktu perkawinan akan dapat beradaptasi dengan keadaan dan konflik-konflik dalam sebuah rumah tangga itu sendiri.

Hal ini sesuai dengan penelitian yang dilakukan oleh Oktary, dkk, (2014), yang mengatakan bahwa umur kawin pertama tidak berpengaruh terhadap terjadinya cerai gugat di Kota Pekanbaru.

Umur kawin pertama tidak berpengaruh secara signifikan terhadap probabilitas tinggi rendahnya cerai hidup wanita di Pulau Sumatera. Artinya berapapun umur kawin pertamanya, tidak mempengaruhi peluang seorang wanita untuk bercerai.

\section{KESIMPULAN}

Berdasarkan data SDKI 2017 menunjukkan bahwa angka cerai hidup wanita di pulau Sumatera yaitu sebesar 2,9 persen. Berdasarkan faktor demografi: pendidikan istri, jumlah anak, dan pekerjaan istri berpengaruh signifikan terhadap peluang tinggi rendahnya tingkat cerai hidup wanita di Pulau Sumatera. Istri dengan pendidikan rendah, memiliki peluang cerai hidup lebih tinggi daripada istri dengan pendidikan tinggi. Istri yang memiliki jumlah anak sedikit, berpeluang lebih tinggi terhadap cerai hidup 
Jurnal SOSIO DIALEKTIKA 6 (1) (2021)

P-ISSN: 2540.8941 e-ISSN: 2623.2944

sosiodialektika@unwahas.ac.id
Determinan Variabel Demografi

Terhadap Cerai Hidup Wanita

Di Pulau Sumatera: Survei

Demografi Dan Kesehatan

Indonesia 2017

wanita dibandingkan dengan wanita yang memiliki banyak anak. Sedangkan pekerjaan wanita sebagai pekerja informal, berpeluang lebih rendah terhadap cerai hidup wanita dibandingkan dengan wanita yang bekerja sebagai pekerja informal. Sementara untuk umur kawin pertama tidak berpengaruh secara signifikan terhadap cerai hidup wanita. Artinya berapapun usia kawin pertama seorang wanita, tidak menyebabkan tinggi atau rendahnya peluang wanita untuk bercerai.

\section{Rekomendasi}

(1) Pemerintah diharapkan lebih memberikan perhatian terutama melalui kebijakan-kebijakan yang dapat meningkatkan ketahanan keluarga. Salah satu kecenderungan untuk bercerai adalah tingkat pendidikan yang rendah. Oleh sebab itu kebijakan pemerintah melalui program belajar diharapkan dapat meningkatkan jenjang pendidikan yang harus di tamatkan oleh warga masyarakat. Harapannya, semakin tinggi tingkat pendidikan (terutama pendidikan wanita) akan menekan peristiwa cerai hidup dan mengurangi risiko-risiko lain yang berhubungan dengan wanita secara umum.

(2) Diharapkan kepada pasangan suami istri untuk membicarakan keinginannya mengenai jumlah anak yang akan dimiliki. Sehingga tidak menimbulkan konflik dalam sebuah hubungan rumah tangga. Diharapkan juga kepada pemerintah untuk dapat memberikan sosialisasi terhadap masyarakat bahwa kualitas dari anak jauh lebih baik daripada kuantitas.

(3) Selain itu, diharapkan kepada pasangan suami istri untuk mengutamakan diskusi dengan pasangan daripada egoismenya. Mengingat ekonomi adalah hal utama dalam sebuah rumah tangga. Istri yang bekerja formal tujuannya juga untuk membantu perekonomian keluarga, sehingga alangkah baiknya suami juga ikut membantu istri dalam mengurus pekerjaan rumah. Dengan demikian istri dapat melakukan peran ganda dalam kerja dan keluarga, 
Jurnal SOSIO DIALEKTIKA 6 (1) (2021)

P-ISSN: 2540.8941 e-ISSN: 2623.2944

sosiodialektika@unwahas.ac.id
Determinan Variabel Demografi

Terhadap Cerai Hidup Wanita

Di Pulau Sumatera: Survei

Demografi Dan Kesehatan

Indonesia 2017

(4) Meskipun Umur Kawin Pertama tidak berpengaruh signifikan terhadap kasus cerai hidup wanita, namun alangkah baiknya bagi wanita untuk menunda terlebih dulu perkawinannya. Hal ini bermanfaat untuk mengurangi risiko bagi perempuan untuk melahirkan.

\section{Ucapan Terima Kasih}

Ucapan terima kasih penulis sampaikan kepada Ibu Dr. Azizah Husein, M.Pd, Bapak Dr. Yusuf Hartono, Ibu Dr. Dra. Nengyanti, M.Hum, Ibu Dr. Yunisvita, M.Si, Ibu Dr. Dra. Retna Mahriani, M.Si, dan Bapak Dr. Bambang Suprihatin, M.Si.

\section{Konflik Kepentingan}

Penulis menyatakan tidak memiliki konflik kepentingan dalam penelitian dan penulisan artikel ini.

\section{DAFTAR PUSTAKA}

Ascandra, Willi. 2019. Analisis Ekonomi Perceraian Wanita Bekerja Di Provinsi Sumatera Barat. Tesis Universitas Andalas.

Badan Pusat Statistik. 2016. Profil Penduduk Indonesia: Hasil Survei Penduduk Antar Sensus 2015. BPS Nasional

BKKBN, BPS, Kementerian Kesehatan, Measure DHS, dan ICF International. 2017. Laporan Survei Demografi dan Kesehatan Indonesia 2017 dan Daftar Pertanyaan Wanita. BPS Nasional

Dariyo, A. 2004. Memahami Psikologi Perceraian Dalam Kehidupan Keluarga. Jurnal Psikologi Vol. 2 No. 2, Desember 2004.

Devy, Soraya., Firdaus, Muhammad. 2019. Cerai Thalaq di Kalangan Isteri Karier (Studi Kasus di Mahkamah Syari'ah Banda Aceh). Jurnal Hukum Keluarga dan Hukum Islam. Volume 3 No. 2. Juli-Desember 2019 ISSN: 2549 - 3132; E-ISSN: $2549-3167$

Dunvall dan Miller. 1998. Marriage and family development. Journal of Family Psychology, 20(4), 447- 463.

Febria, D,. Yazid, M,. Malahayati, N. 2018. Determinan Partisipasi Keluarga Berencana Pada Keluarga Pra Sejahtera Di Provinsi Sumatera Selatan: 
Jurnal SOSIO DIALEKTIKA 6 (1) (2021)

P-ISSN: 2540.8941 e-ISSN: 2623.2944

sosiodialektika@unwahas.ac.id
Determinan Variabel Demografi

Terhadap Cerai Hidup Wanita

Di Pulau Sumatera: Survei

Demografi Dan Kesehatan

Indonesia 2017

Analisis Data Survei Demografi Dan Kesehatan Indonesia 2012. Jurnal Inovasi Vol. 15 No. 1 Mei 2018: 23-31

Hurlock, E. B. 1991. Psikologi Perkembangan: Suatu Pendekatan Sepanjang Rentang Kehidupan (5th ed). Jakarta: Erlangga

Khumas, Asniar. 2015. Model Penjelasan Intensi Cerai Perempuan Muslim di Sulawesi Selatan. Jurnal Psikologi, 42 (3) : 9 - 20.

Mahapadiat., Monica. 2019. Izin Perceraian Bagi Aparatur Sipil Negara (ASN)

Dan Penyelesaiannya Di Pengadilan Agama Kelas 1A Padang Berdasarkan Putusan Nomor 270/Pdt.G/2019/PA Padang. Tesis Universitas Andalas

Mahmudah, N.A. 2008. Pengaruh Tingkat Pendidikan dan Latihan Kerja terhadap Kualitas Kerja Karyawan pada CV Sahabat Klaten. Skripsi (tidak diterbitkan) Surakarta: Fakultas Keguruan dan Ilmu Pendidikan UMS

Matondang, A. 2014. Faktor-faktor yang mengakibatkan perceraian dalam perkawinan di desa Harapan Kecamatan Tanah Pinem Kabupaten Dairi. Jurnal Ilmu Pemerintahan dan Sosial Politik, 2 (2) (2014): 141-150

Notoatmodjo. 2010. Peningkatan Kualitas Pendidikan. Bandung: Erlangga.

Oktary, N., Sari, L., Maulida, Y. 2014. Analisis faktor-faktor yang mempengaruhi tingkat cerai gugat di Kota Pekanbaru. JOM FEKON Vol. 1 No. 2.

Prasetyo, B. 2017. Perspektif Undang-Undang Perkawinan Terhadap Perkawinan Di Bawah Umur. Jurnal Ilmiah UNTAG Semarang. ISSN : 2302-2752, Vol. 6 No. 1, 2017135.

Wahyudi, I. 2018. Faktor-faktor Dominan Penyebab Terjadinya Perceraian Di Lingkungan Yuridis Peradilan Agama Dalam Perspektif Gender. Tesis Universitas Islam Negeri Syarif Hidayatullah: Jakarta.

Widayanti, A., Lestari, P. 2014. Faktor-faktor Penyebab Perceraian Pada Keluarga Tenaga Kerja Wanita (Tkw) Di Desa Citembong, Kecamatan Bantarsari, Kabupaten Cilacap. Universitas Negeri Yogyakarta.

Wulandari, Sri, S. 2013. Pola Komunikasi Wanita Karier Dalam Mempertahankan Keharmonisan Keluarga Di Kelurahan Bahu. Jurnal Acta Diuma. Vol. II/No.2/2013

Yunus, A. R. K.. Prasetyo. K. A., Mandaku. V. Variabel-Variabel Yang Memengaruhi Cerai Hidup Wanita Di Pulau Jawa (Analisis Data Sdki Tahun 2012) https://www.academia.edu/29676669. 